\title{
AGGRESSIVE BEHAVIOR AND SUICIDE PROBABILITY IN ADOLESCENT MALES
}

\author{
By \\ Mohammed Mohammed Abd El-Khalik El-Deeb \\ Department of Psychiatry, Faculty of Medicine, Al-Azhar University \\ E-mail: deeb17777@gmail.com
}

\begin{abstract}
Background: Aggressive behavior and probability of suicide in adolescents are increased in last decades this affects most communities in our world increasing and socio-economic burden and stress health care facilities.

Objective: To compare suicide probability and aggressive behavior in rural and urban areas and relation between probability of suicide and aggressive behavior in adolescents.

Patients and Methods: Total sample of this study was 295 male student, 105 student from Zorkan secondary school at Zorkan Village, Tala Center, El-Menofeya Governorate and 190 students from Khalil Agha secondary school in Bab El-Sheria Cairo Governorate selected in random manner. All participants were subjected to suicide probability scale, semi-structured clinical psychiatric interview and socioeconomic standard form during the period from December 2019 to April 2020.
\end{abstract}

Results: This study revealed that there was a high suicide risk in the sample divided into three groups: group of mild risk (46.1\%), group of moderate risk (25.1\%) and group of sever risk (11.9\%), Suicide risk increased in urban sample than rural sample in statistical significant degree, There was a positive correlation between suicide risk and aggressive behavior in statistical significant degree, Prevalence of psychiatric disorders was $(11.53 \%)$ in the total sample, $(11.58 \%)$ in urban sample and $(11.435 \%)$ in rural sample, Prevalence of depression in rural sample was $(8.57 \%)$ and $(7.89 \%)$ in urban sample while prevalence of generalized anxiety disorder in rural sample was $(2.86 \%)$ and in urban sample was $(2.635 \%)$, Prevalence of obsessivecompulsive disorder in urban sample was $(1.05 \%)$ and no cases in rural sample, there was a positive correlation between suicide probability, aggressive behavior and psychiatric morbidity in a significant degree in the sample as a whole.

Conclusion: Suicide probability and aggression in adolescents was increased in urban areas in Egypt than in rural areas also the increasing rate of aggressive behavior increased the rate of probability of suicide in adolescents.

Key words: Aggressive behavior, Suicide probability, Adolescents.

\section{INTRODUCTION}

Current Centers for Disease Control and Prevention (CDC) data indicate that suicide is the second leading cause of death for both children and adolescents ages 10 to 17 , second to only unintentional injury $(C D C, 2017)$. This statistic is an evidence of rising rates of suicide among children and adolescents, as ten years prior, suicide was the fourth leading cause of death among children ages 10 to 17 (CDC, 2017) Furthermore, suicide is now the 9th leading cause of death among children ages 5 to 11 (CDC, 2017). Unfortunately, these death statistics comport with recent literature which found a 92\% increase in annual emergency department (ED) visits for suicide ideation and attempts from 2007 to 2015 for children under the age of 18 , 
despite no statistically significant increase in the overall number of ED visits (Burstein, Agostino, \& Greenfield, 2019).

Those admitted to the ED for a suicide attempt increased by $79 \%$ from 2007 to 2015 , and almost half $(43.1 \%)$ of all ED visits for suicide ideation or a suicide attempt were for children between the ages of 5 and 10 (Burstein et al., 2019), Rising rates of suicide attempts and death, particularly in younger children, indicate the urgent need to develop a better understanding of contributing risk factors to increased suicide risk and to design new evidence, based interventions for suicide in children and adolescents. As such, our special issue is organized in two sections: (1) papers that highlight contributing risk factors of increased suicide risk and (2) papers describing new treatments for suicide in children and adolescents. In order to effectively prevent and intervene, it is critical to build an empirically based Conceptualization of the contributing factors that increase child and adolescent suicide. In this section on contributing risk factors, the authors review unique factors that increase suicide risk including anxiety, sleep problems, child sexual abuse, and violent victimization. Notably, there are other factors that are not included in the present issue that also contribute to increased risk e.g., seasonal trends with higher rates of suicide attempts in the school year selfharm (Carbone et al., 2019). To begin the special issue and open the section on risk factors, Covert and Fraire (2019) provided a comprehensive review of the literature on how specific anxiety disorders may serve as risk factors for Suicide-related behavior in youth. An important take away from their review, is the relative lack of research on the role of anxiety disorders and suicide in youth. They concluded that social anxiety disorder appears to have the most developed literature, with the presence of social anxiety disorder related to increased risk for suicide-related behavior in adolescents. Additionally, generalized anxiety disorder also serves as a risk factor for suicidal behavior in adolescents. Importantly, the Covert and Fraire (2019) article made a relevant clinical suggestion: when determining a child or adolescent's suicide risk, we should not only be examining this within the context of depression -which is most commonly done in clinical practice - but also anxiety disorders, particularly given their high comorbidity with depression. Aggression is a ubiquitous and important phenomenon, and manifests itself through thoughts, feelings, desires, fantasies, through the motions and behavior of young people. Aggressiveness in adolescence can often be an expression of conscious and unconscious efforts of separation from parents, autonomy and personal independence (Kongres et al., 2011). It is mainly manifested in rebellion to the environment, constantly confronting parents and authority, verbal aggression, physical aggression, neglect of school responsibilities, as well as more dangerous situations such as speeding, alcohol abuse, experimentation with drugs, thoughts of death, suicide attempt (Carbone et al., 2019).

\section{PATIENTS AND METHODS}

This study was done at two schools the first one was Zorkan secondary at Zorkan village Tala center, Menofeya Governorate, this school received students 
from Zorkan and surrounding villages and number of students was 460 students. The second school was Khalil Agha secondary school which contained 1010 students and present at Bab El-Shàaria, Cairo Governorate where socioeconomic level is below moderate, most peoples at this neighborhood work in different professions Most of it are manual and craft professions, with a few related scientific jobs, such as doctors and engineers during the period from December 2019 to April 2020.

Stage of field study: Researcher accompanied the school administrator of Zorkan secondary school and school doctor of Khalil Agha School applying suicide probability questionnaire and the socioeconomic level form for all members of the sample and explaining how to fill them. He conducted a semi-structured clinical interview according to DSM 5 for all members of the sample, He corrected suicide probability questionnaire, socioeconomic level form collecting their results and collecting results of clinical interviews then the researcher did the statistical processing by help of professionals at this field, The study was conducted on two samples: the first was
105 students at Zorkan secondary school who were all male students at all classrooms which were 2 classrooms at 1 st year, 2 classrooms at 2 nd year and 2 classrooms at 3 rd year each class room contained 45 student after excluding absent students who were 146 student and other 3 students refused sharing in the study, the second sample was 190 male students from Khalil Agha secondary school they were selected randomly from total number 1010 student each class room contained 50 students.

Statistical analysis: Two types of statistics were done:

\section{Descriptive statistics:}

- Quantitative data was shown as mean, $\mathrm{SD}$, and range.

- Qualitative data was expressed as frequency and percent.

2. Analytical statistics: Mann Whitney test was used to compare mean and $\mathrm{SD}$ of 2 sets of quantitative when this data is not normally distributed. Post hoc test was used for specific differences between three or more groups, $\mathrm{P}$ value was considered statistically significant when $\mathrm{p} \leq 0.05$.

\section{RESULTS}

It was found that mild suicide risk is the most is the most followed by moderate suicide risk then severe suicide risk (Table 1).

Table (1): Ratio of suicide probability in the sample

\begin{tabular}{|c|c|c|}
\hline Suicide risk & Number & Percentage \\
\hline Subclinical & 50 & $16.9 \%$ \\
\hline Mild & 136 & $46.1 \%$ \\
\hline Moderate & 74 & $25.1 \%$ \\
\hline Severe & 35 & $11.9 \%$ \\
\hline Total & 295 & $100 \%$ \\
\hline
\end{tabular}


It was found also that that probability of suicide in rural group is less than

probability of suicide in urban group with statistical significance (Table 2).

Table (2): Relation between rate of probability of suicide and residence

\begin{tabular}{|c|c|c|c|c|c|c|}
\hline \multirow{2}{*}{ Residence } & \multirow{2}{*}{ Variables } & \multicolumn{3}{|c|}{ Probability of suicide } & \multirow{2}{*}{ Total } \\
\cline { 2 - 7 } & Number & 12 & 65 & 22 & 6 & 105 \\
\hline \multirow{3}{*}{$\begin{array}{c}\text { Rural } \\
\text { Group }\end{array}$} & Ratio to residence group & $11.4 \%$ & $61.9 \%$ & $21 \%$ & $5.7 \%$ & $100 \%$ \\
\cline { 2 - 7 } & Ratio to probability group & $24 \%$ & $46.1 \%$ & $29.7 \%$ & $20 \%$ & $35.6 \%$ \\
\cline { 2 - 7 } & Ratio to total sample & $4.1 \%$ & $22 \%$ & $7.5 \%$ & $2 \%$ & $35.6 \%$ \\
\hline \multirow{3}{*}{$\begin{array}{c}\text { Urban } \\
\text { Group }\end{array}$} & Number & 38 & 76 & 52 & 24 & 190 \\
\cline { 2 - 7 } & Ratio to residence group & $20 \%$ & $40 \%$ & $27.4 \%$ & $12.6 \%$ & $100 \%$ \\
\cline { 2 - 7 } & Ratio to probability group & $76 \%$ & $53.9 \%$ & $70.3 \%$ & $80 \%$ & $64.4 \%$ \\
\cline { 2 - 7 } & Ratio to total sample & $12.9 \%$ & $25.8 \%$ & $17.6 \%$ & $8.1 \%$ & $64.4 \%$ \\
\hline \multirow{5}{*}{ the total } & Number & 50 & 141 & 74 & 30 & 295 \\
\cline { 2 - 7 } & Ratio to residence group & $16.9 \%$ & $47.8 \%$ & $25.1 \%$ & $10.2 \%$ & $100 \%$ \\
\cline { 2 - 7 } & Ratio to probability group & $100 \%$ & $100 \%$ & $100 \%$ & $100 \%$ & $100 \%$ \\
\cline { 2 - 7 } & Ratio to total sample & $16.9 \%$ & $47.8 \%$ & $25.1 \%$ & $10.2 \%$ & $100 \%$ \\
\hline
\end{tabular}

It was found that there was statistically significance at 0.001 for group higher in degree of suicide probability scale, so probability of suicide is increased with increasing of aggression and imagination of suicide (Table 3).

Table (3): Relation between probability of suicide, aggression and imagination of suicide

\begin{tabular}{|c|c|c|c|c|c|c|}
\hline Values & Groups & Number & Average & $\begin{array}{l}\text { Standard } \\
\text { deviation }\end{array}$ & Significance & $\begin{array}{l}\text { For group } \\
\text { of }\end{array}$ \\
\hline \multirow[b]{2}{*}{ t-degree } & Patient group & 39 & 53.31 & 9.4 & \multirow[b]{2}{*}{$<0.001$} & \multirow{2}{*}{$\begin{array}{l}\text { group } \\
\text { higher in } \\
\text { probability } \\
\text { of suicide }\end{array}$} \\
\hline & $\begin{array}{l}\text { group higher } \\
\text { in degree }\end{array}$ & 64 & 68.34 & 6.16 & & \\
\hline \multirow[b]{2}{*}{$\begin{array}{l}\text { Probability } \\
\text { Of suicide }\end{array}$} & Patient group & 39 & 40.9 & 6.35 & \multirow[b]{2}{*}{$<0.001$} & \multirow{2}{*}{$\begin{array}{l}\text { group } \\
\text { higher in } \\
\text { probability } \\
\text { of suicide }\end{array}$} \\
\hline & $\begin{array}{l}\text { group higher } \\
\text { in degree }\end{array}$ & 64 & 50.8 & 4.2 & & \\
\hline \multirow{2}{*}{$\begin{array}{c}\text { Imagination } \\
\text { Of suicide }\end{array}$} & Patient group & 39 & 14.31 & 4.82 & \multirow[b]{2}{*}{$<0.001$} & \multirow{2}{*}{$\begin{array}{l}\text { group } \\
\text { higher in } \\
\text { probability } \\
\text { of suicide }\end{array}$} \\
\hline & $\begin{array}{l}\text { group higher } \\
\text { in degree }\end{array}$ & 64 & 22.05 & 5.33 & & \\
\hline \multirow[b]{2}{*}{ Aggression } & Patient group & 39 & 12.38 & 3.35 & \multirow[b]{2}{*}{$<0.001$} & \multirow{2}{*}{$\begin{array}{l}\text { group } \\
\text { higher in } \\
\text { probability } \\
\text { of suicide }\end{array}$} \\
\hline & $\begin{array}{l}\text { group higher } \\
\text { in degree }\end{array}$ & 64 & 15.64 & 3.26 & & \\
\hline \multirow[b]{2}{*}{$\begin{array}{l}\text { Total scale } \\
\text { Degree }\end{array}$} & Patient group & 39 & 61.85 & 14.73 & \multirow[b]{2}{*}{$<0.001$} & \multirow{2}{*}{$\begin{array}{l}\text { group } \\
\text { higher in } \\
\text { probability } \\
\text { of suicide }\end{array}$} \\
\hline & $\begin{array}{l}\text { group higher } \\
\text { in degree }\end{array}$ & 64 & 84.20 & 8.61 & & \\
\hline
\end{tabular}


It was found also that major depressive disorder has the highest ratio in the sample then generalized anxiety disorder then obsessive compulsive disorder and that psychiatric disorders are mildly increased in urban group than rural group, with mildly increased in urban group than rural group (Table 4).

Table (4): Comparison between rural and urban group regarding results of clinical interview

\begin{tabular}{|c|c|c|c|c|c|c|}
\hline \multirow{2}{*}{ Groups } & \multicolumn{2}{|c|}{$\begin{array}{c}\text { Rural group 105 } \\
\text { student }\end{array}$} & \multicolumn{2}{c|}{$\begin{array}{c}\text { Urban group 190 } \\
\text { student }\end{array}$} & \multicolumn{2}{c|}{ Total 295} \\
\cline { 2 - 7 } & number & $\%$ & number & $\%$ & number & $\%$ \\
\hline $\begin{array}{c}\text { Major } \\
\text { depression }\end{array}$ & 9 & $8.57 \%$ & 15 & $7.89 \%$ & 24 & $8.14 \%$ \\
\hline $\begin{array}{c}\text { Generalized } \\
\text { anxiety }\end{array}$ & 3 & $2.86 \%$ & 5 & $2.63 \%$ & 8 & $2.71 \%$ \\
\hline $\begin{array}{c}\text { Obsessive } \\
\text { compulsive }\end{array}$ & - & - & 2 & $1.05 \%$ & 2 & $0.68 \%$ \\
\hline Total & 12 & $11.43 \%$ & 22 & $11.58 \%$ & 34 & $11.53 \%$ \\
\hline $\begin{array}{c}\text { Family history } \\
\text { of psychiatric } \\
\text { disorder }\end{array}$ & 3 & $2.86 \%$ & 6 & $3.16 \%$ & 9 & $3.05 \%$ \\
\hline
\end{tabular}

\section{DISCUSSION}

This work showed an increase in the ratio of suicide probability in the sample, as the ratio of suicide probability was $46.1 \%$, The ratio of moderate suicide probability was $25.1 \%$, while severe suicide probability was $11.9 \%$, This may be due to socioeconomic stressors that affect adolescents, sense of hope loss, sense of despair, difficulty in having work and house also difficulty in marriage this result is supported by study of (Neelman and Lewis, 2015) that had confirmed increased rate of suicide among adolescents at last decade of twenty century.

There was an increase in rate of probability of suicide in urban group more than rural group with statistical significance, this may be due to relative simplicity of life in rural areas than in urban areas as rural areas were less crowded and easier to have house and get married. Also, rural areas were less in pollution and social support was better at rural community than urban community. This may decrease rate of psychiatric disorders. The present work was supported by Study of (Leighton et al., 2011) showed that the rate of psychiatric disorders was (25\%) (Leighton D.C. et al., 2011). Study of Samuels (2014) who found that the rate of spread of psychiatric disorders was (34\%). Study of the survey area in USA by (Darel et al., 2012) who found that the psychiatric disorders were $(36 \%)$ in males and $(30 \%)$ in females Study of (Jhonson et al., 2019) who stated that the social support and suitable rearing of adolescents play an important role in decreasing suicidal behaviors. The probability of suicide was increased with the increase of aggressive behavior and imagination of suicide with statistical significance; this was supported by the study of (Swogger et al., 2015) who found increasing of suicide with the increasing of aggression. The present work found 
that major depressive episode had the highest rate in the sample $(8.57 \%)$ in rural sample and $(7.89 \%)$ in urban sample while generalized anxiety disorder had less rate of $(2.86 \%)$ in rural sample and $(2.63 \%)$ in urban sample, Also obsessive compulsive disorder was present in urban sample only with a rate of $(1.05 \%)$. There was family history of psychiatric disorder in rural sample with rate of $(2.86 \%)$ and in urban sample with rate of $(3.16 \%)$. The total psychiatric disorders was $(11.43 \%)$ in rural sample and $(11.58 \%)$ in urban sample which were near rates, this was supported by Study of (Silva et al, 2020) who found that the rate of mental disorders was $(31 \%)$ in male adolescents and $(25 \%)$ in female adolescents. The difference in results between our study and these studies may be due to difference in size, method of selection and specification of sample, the use of different diagnostic methods as general health questionnaire and dependence on patient record in Lighton study and socioeconomic differences of persons shared in our study and the previous studies.

\section{CONCLUSION}

Suicide probability and aggression in adolescents increased in urban areas in Egypt than in rural areas. Also the increasing rate of aggressive behavior increased the rate of probability of suicide in adolescents.

\section{REFERENCES}

1. Burstein, B., Agostino, H., and Greenfield, B. (2019): Suicidal attempts and ideation among children and adolescents in US emergency departments, JAMA Pediatrics, 173:598.

2. Carbon.J. T., Holzer, K. J., and Vaughn, M. G. (2019): Child and adolescent suicidal ideation and suicide attempts: Evidence from the healthcare cost and utilization project. The Journal of Pediatrics, 206, 225-231.

3. Darel, A. Ragier and Charles, T (2012): Textbook of psychiatric epidemiology. Psychol Violence Edited by Trsuong Willew, Liss. In. 220:7-13.

4. Jonson, Madelyn-S, K., Stephanie M. Brown T. Jocelyn B. and Judith S. (2019): Childhood adversities, interpersonal difficulties and risk for suicide attempts during late adolescence and early adulthood. The Journal of Pediatrics, 107, 215-251.

5. Leighton D.C., Harding S. and Machlin D.B. (2011): The Character of danger vol.1,3 of the Stirling country study N.Y. Basic books. 107: 6-12.

6. Swogger, M., Kemberly A. Van O. and Kenneth R. (2015): The relationship of outwardly-directed aggression to suicidal ideation and suicide attempts across two highrisk samples, Psychol Violence. 4(2): 184195.

7. Neelman J. and Lewis G, (2015): Suicide, Religion and socioeconomic conditions. An ecological study in 26 countries, J Epidemiol Community Health; 53(4):204-10.

8. Samuels J.F. (2014): The detection of mental disorders in community using 20 item interview version of GHQ. Acta, Psych. Scand, 89:4-20.

9. Silva S. Silva S.U. Debora B.R. and Kenia M. (2020): Common mental disorders prevalence in adolescents: A systematic review and meta-analyses, Journal of American Academy Child Adolescent Pychiatry 38(1): 56-63.. 


\section{السلو ك العدو اني و احتمالبة الانتحار في المر اهفين الذكور محمد محمد عبد الخالق الديب}

قسم الطب النفسي، كلية الطب، جامعة الأزهر

E-mail: deeb17777@gmail.com

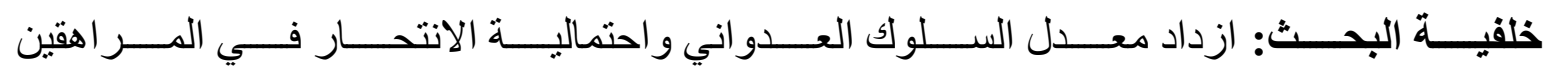

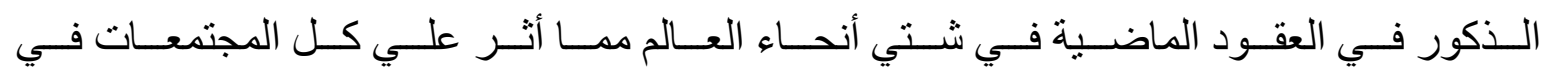

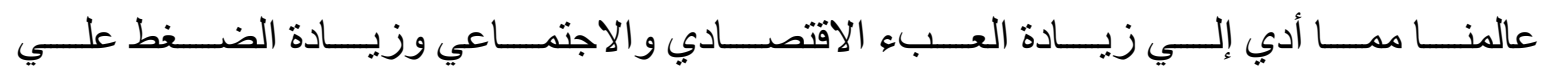

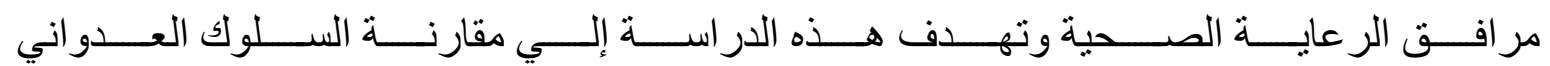

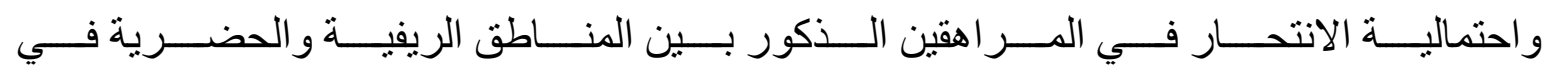

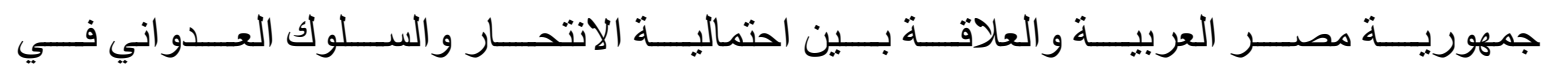

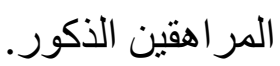

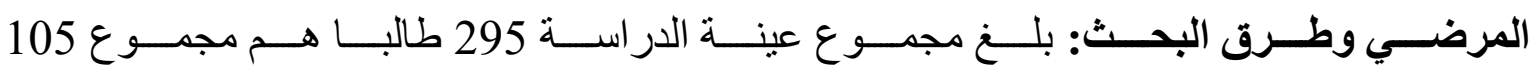

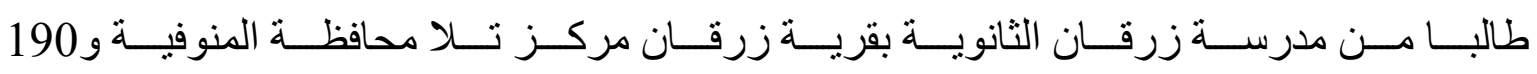

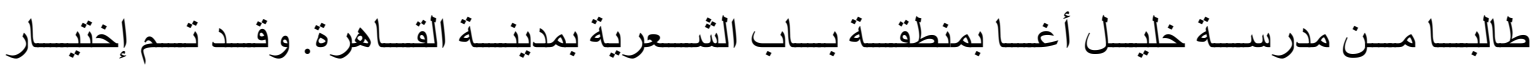

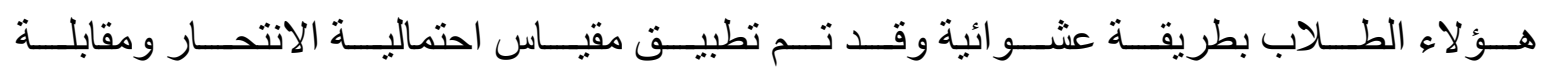

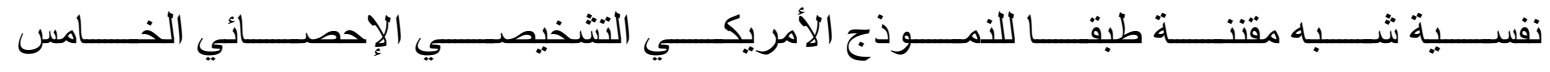

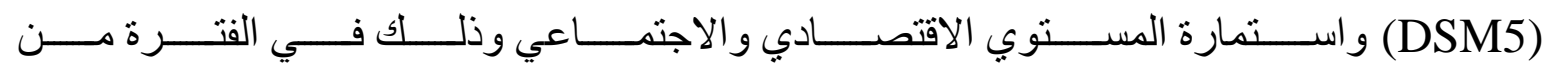
ديسمبر 2019 وحتي إبريل وبعد عمل الإجر اءات الإحصائية اللازمة.

نتائج البحث:

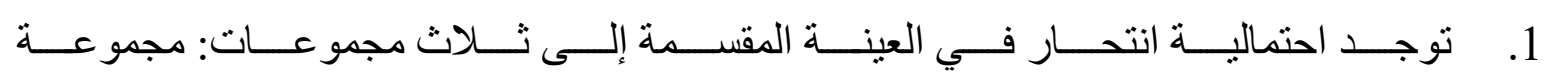

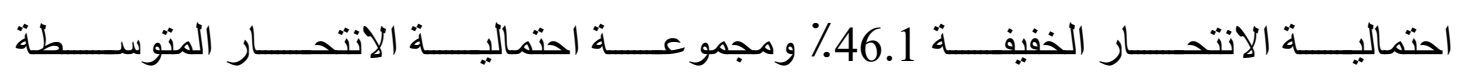

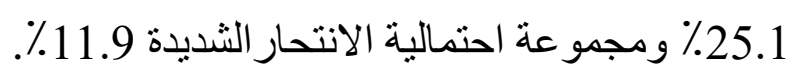

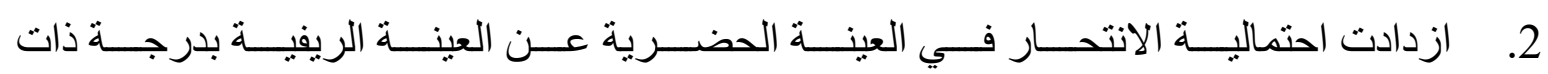
دلالة إحصائية. 


\section{MOHAMMED A. EL-DEEB}

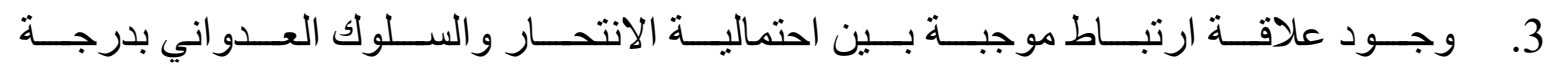
ذات دلالة إحصائية.

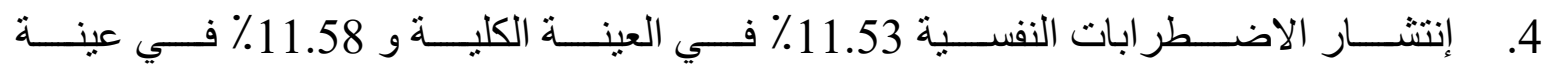
الحضر و 11.435\% في عينة الريف.

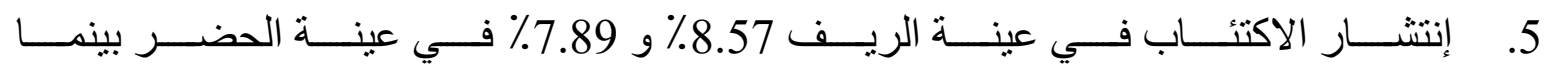

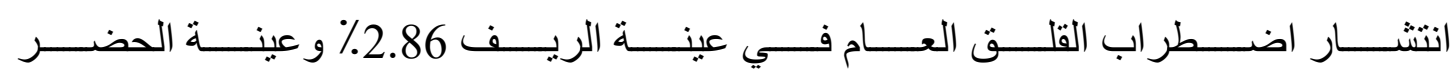
$\% 2.635$

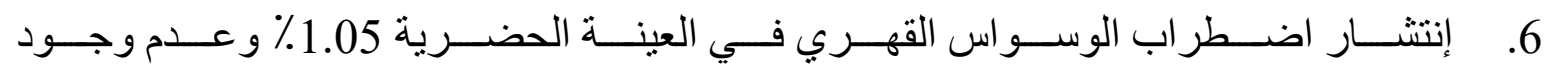

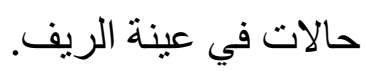

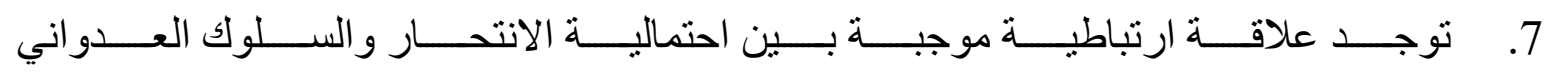
و الاضطر ابات النفسية بدرجة دالة احصائيا في العينة ككل.

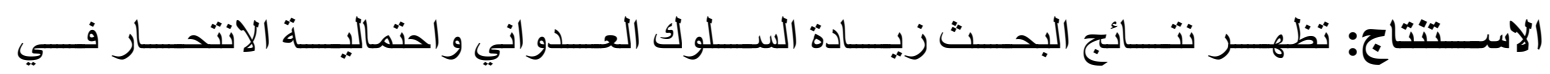

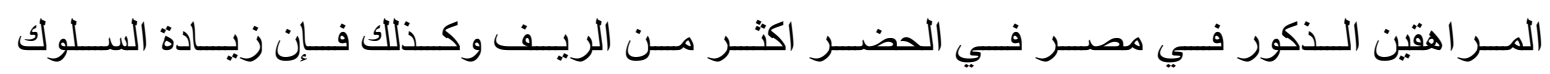
العدو اني في المر اهقين الذكور تزيد من احتمالية الانتحار لديهر. الكلمات الدالة: السلوك العدو اني، احتمالية الانتحار ، المر اهقون. 